\title{
Efficacy of amino acid based commercial formulate and potassium nitrate on productivity of Zizyphus mauritiana Lamk. Cv. Seo in Central India
}

\begin{abstract}
The present study was carried out in a well established experimental field of Zizyphus mauritiana (ber) at ICAR-Central Agroforestry Research Institute, Jhansi during 2012 and 2013, to assess the efficacy of foliar spray of amino acid based commercial formulate i.e. HiFoliar nutrient and potassium nitrate $\left(\mathrm{KNO}_{3}\right)$ on fruit attributes and yield of ber cv. Seo in semi-arid tropics of Central India. The experiment, comprising of twelve treatments with four replications was laid out in completely randomized block design. The HiFoliar nutrient and potassium nitrate was sprayed three times at the interval of fifteen days starting in December and recorded observations on fruit yield and yield attributes. The findings revealed that in ber HiFoliar Nutrient is only effective when used with $\mathrm{KNO}_{3}$. In general, most of the fruit characters influenced by application of treatment $\mathrm{T} 5\left(\mathrm{KNO}_{3} 1.0 \%\right)$ and T11 (HiFoliar $0.4 \%+\mathrm{KNO}_{3} 1.0 \%$ ) except pulp/stone ratio and TSS wherein treatment T9 (HiFoliar $0.3 \%+\mathrm{KNO} 31.0 \%$ ) was most effective. The study concludes that three spray of treatment T5 (KNO3 1.0\%) at the interval of fifteen days at marble stage of fruits enhances growth, fruit quality and yield of ber cv. Seo.
\end{abstract}

Keywords: growth, hifoliar nutrient, yield and zizyphus mauritiana
Volume 6 Issue 6 - 2018

\author{
Sudhir Kumar, Rajendra Prasad, GS Kaurav \\ ICAR-Central Agroforestry Research Institute, Uttar Pradesh, \\ India
}

Correspondence: Sudhir Kumar ICAR-Central Agroforestry Research Institute, Jhansi - 284 003, Uttar Pradesh, India, Email dr65sudhirkumar@yahoo.co.in

Received: June 14, 2018 | Published: December 31, 2018

\section{Introduction}

The ber (Zizyphus species), originated in India, China and Malaya regions, belongs to family Rhamnaceae which consists of 45 genera and 550 species. It is widely distributed in tropical and subtropical climates in the world. ${ }^{1}$ In India, major ber growing states are Madhya Pradesh, Bihar, Uttar Pradesh and Punjab. It is also grown in Maharashtra, Rajasthan, Tamil Nadu, Assam, Andhra Pradesh and West Bengal. It is the most ancient and common fruit cultivated in India. It has a long historic background and mentioned in Sanskrit literature as well. Being an ideal tree for arid and semi-arid regions due to its hardy and salt tolerant nature, the tree can grow in marginal lands. Ber fruit is a rich nutritional source for energy, protein and minerals. Jujube is one of the world's most nutritious fruit rich in $\mathrm{P}, \mathrm{K}, \mathrm{Fe}$, vitamin $\mathrm{C}$ and amino acids. ${ }^{2,3}$ Ber is one of the important component of agroforestry systems particularly in arid and semi-arid tropics. Agri-horti system comprising Zizyphus + mungbean provided fruit, fuel wood and round year employment even in below average rainfall year. Studies revealed that the yields of both jujube and the intercrops were higher than in monoculture. ${ }^{4}$

There are number of chemicals, growth regulators and commercial formulates available in the market which affects growth and yield of agricultural as well as horticultural crops. Recently, a new commercial formulate named HiFoliar nutrient, a blend of amino acids extracted from vegetables and being manufactured by HiMedia, which claims its effectiveness on growth and yield of agricultural as well as horticultural crops by using $300 \mathrm{~g}$ of the product in 100 liters of water. The amino acid ratio in HiFoliar nutrient is similar to the amino acid ratio in plant tissues. HiFoliar nutrient powder provides readymade source of amino acids (building blocks of protein synthesis) to the plants for growth. The foliar application of macro and micro-nutrients play a very important role in improving fruit set, productivity and quality of fruits. It has also beneficial role in recovery of nutritional and physiological disorders in fruit trees. Various experiments have been conducted earlier on foliar spray of micro-nutrients in different fruit crops and shown significant response to improve yield and quality of the fruits. Among different chemicals used in foliar applications, potassium nitrate $\left(\mathrm{KNO}_{3}\right)$ is such chemical which affects growth and yield of vegetable and fruit crops. ${ }^{5-7}$ Keeping in view the remarkable effect of HiFoliar nutrient as reported by some researchers and effectiveness of potassium nitrate on growth and yield of vegetable and fruit crops, the present investigation was carried out with and without $\mathrm{KNO}_{3}$ to assess the efficacy of HiFoliar nutrient as well as $\mathrm{KNO}_{3}$ on fruit growth and yield of ber cv. Seo in semi-arid conditions of Central India.

\section{Materials and methods}

The present investigation was carried out in two and half years old well maintained ber orchard established at research farm of ICAR-Central Agroforestry Research Institute, Jhansi during 2012 and 2013. Geographically Jhansi is located at $25^{\circ} 27^{\prime} \mathrm{N}$ latitude and $78^{\circ} 35^{\prime} \mathrm{E}$ longitude at an altitude of 271 meter above mean sea level and having semi-arid and sub-tropical climate with extremes of hot in summer. There is a gradual increase in daily temperature from April to May. The rainfall of this region is between 750 to $1100 \mathrm{~mm}$, maximum mean temperature $32.5^{\circ} \mathrm{C}\left(48^{\circ} \mathrm{C}\right.$ in the month of May) and minimum mean temperature $17.7^{\circ} \mathrm{C}\left(1.5^{\circ} \mathrm{C}\right.$ in the month of January). For the study, three doses of HiFoliar nutrient $(0.2,0.3$ and $0.4 \%)$ and two concentrations of $\mathrm{KNO}_{3}(0.5$ and $1.0 \%$ prepared every time fresh) were tested separately and in combinations along with one control wherein only water was sprayed. In total, 12 treatments ( $\mathrm{T}_{1}$-HiFoliar $0.2 \%, \mathrm{~T}_{2}$-HiFoliar $0.3 \%, \mathrm{~T}_{3}$-HiFoliar $0.4 \%, \mathrm{~T}_{4}-\mathrm{KNO}_{3}$ $0.5 \%, \mathrm{~T}_{5}-\mathrm{KNO}_{3} \quad 1.0 \%, \mathrm{~T}_{6}-\mathrm{HiFoliar} \quad 0.2 \%+\mathrm{KNO}_{3} \quad 0.5 \%, \mathrm{~T}_{7}-$ HiFoliar $0.2 \%+\mathrm{KNO}_{3} 1.0 \%, \mathrm{~T}_{8}-\mathrm{HiFoliar} \quad 0.3 \%+\mathrm{KNO}_{3} 0.5 \%$, $\mathrm{T}_{9}-$ HiFoliar $0.3 \%+\mathrm{KNO}_{3} \quad 1.0 \%, \mathrm{~T}_{10^{-}}$HiFoliar $0.4 \%+\mathrm{KNO}_{3} 0.5 \%, \mathrm{~T}_{11}$-HiFoliar $0.4 \%+\mathrm{KNO}_{3} 1.0 \%$ and $\mathrm{T}_{12}$ - Control- water spray) were imposed on ber plants when the fruits attained the diameter of $>15 \mathrm{~mm}$ (marble stage). The experiment was laid out in CRD with four replications and each treatment was having two plants. The plants were sprayed three times at the interval of fifteen days starting from December, 2012. 
The observations were recorded on fruit and yield parameters such as fruit weight, fruit volume, fruit size, pulp weight, stone weight, pulp/stone ratio, total soluble solids (TSS), number of fruits and fruit yield. One-way ANOVA was performed using SPSS software version 11.5 and the two way ANOVA using SYSTAT software version 11. The significance of the results was calculated at $5 \%$ level as per the procedure given by Gomez and Gomez (2010).

\section{Results and discussion}

Data pertaining to fruit characters such as fruit weight $(\mathrm{g})$, fruit volume (cc), fruit size $\left(\mathrm{cm}^{2}\right)$, pulp weight $(\mathrm{g})$, stone weight $(\mathrm{g})$, pulp/ stone ratio and total soluble solids $\left({ }^{\circ} \mathrm{B}\right)$ are presented in Figure 1A. The results are described in different sub-heads of fruit characters as below.

\section{Fruit weight, fruit volume and fruit size}

Fruit weight was significantly higher in most of the treatment as compared to control $\left(\mathrm{T}_{12}\right)$, except in $\mathrm{T}_{1}, \mathrm{~T}_{6}$ and $\mathrm{T}_{10}$. Maximum fruit weight was obtained in $\mathrm{T}_{5}(21.92 \mathrm{~g})$, followed by $\mathrm{T}_{3}(20.82 \mathrm{~g}), \mathrm{T}_{11}$ (19.84 g), $\mathrm{T}_{2}(18.99 \mathrm{~g}), \mathrm{T}_{8}(18.25 \mathrm{~g}), \mathrm{T}_{7}(18.20 \mathrm{~g}), \mathrm{T}_{9}(17.89 \mathrm{~g})$ and $\mathrm{T}_{4}$ $(16.96 \mathrm{~g})$. Results revealed that most of the treatments have improved fruit weight but the degree of improvement differed with each other Further, among the treatments showing better results over control, $\mathrm{T}_{4}$, $\mathrm{T}_{7}$ and $\mathrm{T}_{9}$ were the less effective than the rest of the treatments but were at par with each other. Fruit volume was also found statistically higher over control almost in all the treatments. Maximum volume was obtained in $\mathrm{T}_{5}(22.14 \mathrm{cc})$, followed by $\mathrm{T}_{3}(21.42 \mathrm{cc}), \mathrm{T}_{11}(20.00$ $\mathrm{cc}), \mathrm{T}_{2}(19.99 \mathrm{cc}), \mathrm{T}_{8}(18.69 \mathrm{cc}), \mathrm{T}_{7}(18.35 \mathrm{cc})$ and $\mathrm{T}_{9}(18.28 \mathrm{cc})$ whereas it was recorded minimum in $\mathrm{T}_{1}(13.27 \mathrm{cc})$. As far as fruit size is concerned, $T_{5}\left(10.95 \mathrm{~cm}^{2}\right)$ was found statistically superior over other treatments and control $\left(\mathrm{T}_{12}\right)$. Rest of the treatment did not affect fruit size and remained at par with control $\left(\mathrm{T}_{12}\right)$.

\section{Pulp weight, stone weight, pulp/stone ratio and total} soluble solids (TSS)

All the treatments, except $\mathrm{T}_{1}, \mathrm{~T}_{6}$ and $\mathrm{T}_{10}$ produced significantly higher pulp weight than control $\left(\mathrm{T}_{12}\right)$. Treatment $\mathrm{T}_{5}(20.35 \mathrm{~g})$ was most effective but was at par with $\mathrm{T}_{2}(17.56 \mathrm{~g}), \mathrm{T}_{3}(19.62 \mathrm{~g}), \mathrm{T}_{8}(17.14 \mathrm{~g})$ and $\mathrm{T}_{11}(18.46 \mathrm{~g})$. The treatments $\mathrm{T}_{4}(15.74 \mathrm{~g}), \mathrm{T}_{7}(16.93 \mathrm{~g})$ and $\mathrm{T}_{9}(16.87$ g), though statistically better than control but were less effective than $\mathrm{T}_{5}, \mathrm{~T}_{2}, \mathrm{~T}_{3}, \mathrm{~T}_{8}$ and $\mathrm{T}_{11}$. Minimum pulp weight was recorded in $\mathrm{T}_{1}(11.63$ $\mathrm{g})$. Variation in stone weight was non-significant in all the treatments and found at par with control. However, $\mathrm{T}_{5}$ recorded maximum stone weight (1.52 g) among all the treatments. The minimum stone weight was obtained in $\mathrm{T}_{9}(1.01 \mathrm{~g})$. The findings are in support of the results of Hegazi et al. ${ }^{9}$ who sprayed $4 \%$ and $2 \% \mathrm{KNO}_{3}$ in olive and did not find significant differences in seed weight. In pulp/stone ratio, $\mathrm{T}_{9}$ was found statistically superior among all the treatments. In this treatment, pulp/stone ratio was 16.86 . The other treatments which showed superiority over control were $\mathrm{T}_{3}(16.47), \mathrm{T}_{4}(13.74), \mathrm{T}_{5}(13.50), \mathrm{T}_{7}$ (13.37), $\mathrm{T}_{8}$ (15.71) and $\mathrm{T}_{11}(13.76)$ but found at par with $\mathrm{T}_{9}(16.86)$. The minimum pulp/stone ratio (9.22) was recorded in $\mathrm{T}_{12}$ (control). TSS was also found more $\left(15.29^{\circ} \mathrm{B}\right)$ in $\mathrm{T}_{9}$, followed by $\mathrm{T}_{3}\left(14.93{ }^{\circ} \mathrm{B}\right)$ and both the treatments were statistically superior over control $\left(T_{12}\right)$ and other treatments. Minimum TSS $\left(11.81^{\circ} \mathrm{B}\right)$ was observed in $\mathrm{T}_{6}$.

The results revealed that except pulp/stone ratio and total soluble solids, wherein treatment $\mathrm{T}_{9}$ recorded best result, remaining characters produced maximum value in treatment $T_{5}$. The beneficial effect of potassium on growth, yield and fruit quality may be attributed to their vital role in stimulating cell division and cell elongation as well as the biosynthesis and trans-location of organic foods enhancing growth and fruiting of trees. ${ }^{10}$ These results are in agreement with those obtained by Elsabagh ${ }^{11}$ who reported increase in fruit weight, fruit size and pulp weight in date palm by spraying $\mathrm{KNO}_{3}$ and $\mathrm{K}_{2} \mathrm{SO}_{4}(1 \& 2 \%)$ and $\mathrm{H}_{3} \mathrm{BO}_{3}(2000 \mathrm{ppm})$, and advocated that it could be due to improving cell size or cell number by nutrient elements. The obtained results are in conformation with the results of Hegazi et al. ${ }^{9}$ They had reported that two spray of potassium nitrate at $4 \%$ concentration enhanced nutritional status of trees and improved the vegetative growth, reduced fruit drops and increased productivity, fruit quality and oil content. Yasin et al. ${ }^{12}$ pointed out that application of zinc and potassium was effective in improving the yield, quality parameters and reduced fruit drop of citrus fruits. Inglese et al..$^{13}$ found that foliar application of $\mathrm{KNO}_{3}$, during the second and the third phase of olive growth improved the fresh weight and the flesh to pit ratio. Ben-Mimoum et al. ${ }^{14}$ reported that potassium fertilization improved yield and quality as well as fruit weight and flesh to pit ratio of olive. Sarrwy et al. ${ }^{15}$ concluded that foliar spray with potassium nitrate at $3 \%$ increased fruiting and fruit quality as well as fruit oil contents in olive.

\section{Fruit numbers (fruit retention) and yield}

Data on fruits number and fruit yield ( $\mathrm{kg} / \mathrm{plant}$ ) is depicted in Figure 1, which revealed that treatments had no significant effect on number of fruits per plant. Based on absolute value, the maximum number of fruits (226.63) was recorded treatment $T_{2}$, followed by $T_{11}$ (219). Fruit yield per plant was significantly increased by the $T_{2}, T_{5}$ and $T_{11}$ as compared to $T_{12}$ (control), being maximum value $(4.338$ $\mathrm{kg} / \mathrm{plant})$ in $\mathrm{T}_{11}$ and minimum in $\mathrm{T}_{6}(1.760 \mathrm{~kg} / \mathrm{plant})$. Maximum yield in $T_{11}$ may be attributed to retention of fruits after spray (no further dropping of fruits). The results also revealed that HiFoliar nutrient is more effective when sprayed with $\mathrm{KNO}_{3}$ as compared to spray alone. This could be due to a synergistic effect by both HiFoliar and $\mathrm{KNO}_{3}$, The findings are in conformity with the results of Elsabagh ${ }^{11}$ and Yasin et al. ${ }^{12}$ advocated that application of potassium improved yield and quality parameters, and reduced fruit drop in citrus whereas Elsabagh ${ }^{11}$ reported higher percentage of retained fruits due to $\mathrm{KNO}_{3}$ and $\mathrm{K}_{2} \mathrm{SO}_{4}(1$ and $2 \%)$ and $\mathrm{H}_{3} \mathrm{BO}_{3}(2000 \mathrm{ppm})$ application. Increase in the percentage of retained fruits due to potassium may be attributed to enhanced many metabolic processes such as carbohydrate, ${ }^{16}$ increase in nutrient uptake and sugar translocation as advocated by Hegazi et al. ${ }^{9}$ The present results are also in agreement with the results of Shahin ${ }^{17}$ and Khayyat et al. ${ }^{18}$ in date palm and of Stino et al. ${ }^{19}$ in mango.

\section{Characters association}

Correlation matrix was worked out for assessing association of yield and yield attributes among them. Fruit weight had significant positive correlation with fruit volume $(r=0.998, p>0.01)$, fruit length $(\mathrm{r}=0.817, \mathrm{p}>0.01)$, fruit breadth $(\mathrm{r}=0.819, \mathrm{p}>0.01)$, fruit size $(\mathrm{r}=$ $0.836, p>0.01)$, pulp weight $(r=0.998, p>0.01)$, pulp-stone ratio $(r=$ $0.670, p>0.01)$ and fruit yield $(r=0.573, p>0.01)$. Similarly, most of yield attributing characters (except stone weight) had significant positive correlations among themselves (Table 1). Fruit yield had significant positive correlation with fruit weight $(\mathrm{r}=0.573, \mathrm{p}>0.01)$, fruit volume $(r=0.597, p>0.01)$, fruit length $(r=0.540, p>0.01)$, fruit breadth $(\mathrm{r}=0.510, \mathrm{p}>0.01)$, fruit size $(\mathrm{r}=0.535, \mathrm{p}>0.01)$, pulp weight $(\mathrm{r}=0.574, \mathrm{p}>0.01)$, pulp-stone ratio $(\mathrm{r}=0.388, \mathrm{p}>0.01)$ and fruit numbers $(r=0.914, p>0.01)$. Stone weight did not show significant positive correlation with any of the characters (attributes) but had significantly negative correlation with TSS $(r=-0.323, p>0.01)$ and $\mathrm{pulp} / \mathrm{stone}$ ratio $(\mathrm{r}=-0.611, \mathrm{p}>0.01)$. These findings are in conformity with the results of Abbasi et al. ${ }^{20}$ They observed highly significant 
positive correlations between yield and yield traits of okra by using Super-dawn, Agri-power and Unigrow-C (all foliar fertilizer products like HiFoliar). Kumar et al. ${ }^{7}$ also reported highly significant positive correlations between yield and other fruit characters by using HiFoliar nutrient and potassium nitrate in Zizyphus. The obtained benefits could be due to their multi-nutrient contents, which upon absorption by the leaf tissues improved the growth traits and resultantly increased yield. This notion is further supported by the highly significant positive correlations observed between different parameters studied.

Table I Correlation matrix of fruit characters and yield attributes of ber ( $\mathrm{cr} \mathrm{Seo}$ ) as influenced by spray of HiFoliar Nutrient and Potassium Nitrate $\left(\mathrm{KNO}_{3}\right)$ in Central India

\begin{tabular}{|c|c|c|c|c|c|c|c|c|c|c|c|}
\hline & $\begin{array}{l}\text { Fruit } \\
\text { weight }\end{array}$ & $\begin{array}{l}\text { Fruit } \\
\text { volume }\end{array}$ & $\begin{array}{l}\text { Fruit } \\
\text { length }\end{array}$ & $\begin{array}{l}\text { Fruit } \\
\text { breadth }\end{array}$ & $\begin{array}{l}\text { Fruit } \\
\text { size }\end{array}$ & $\begin{array}{l}\text { Stone } \\
\text { weight }\end{array}$ & $\begin{array}{l}\text { Pulp } \\
\text { weight }\end{array}$ & $\begin{array}{l}\text { Pulp/ } \\
\text { stone } \\
\text { ratio }\end{array}$ & $\begin{array}{l}\text { Total } \\
\text { soluble } \\
\text { solids }\end{array}$ & $\begin{array}{l}\text { Fruit } \\
\text { numbers }\end{array}$ & $\begin{array}{l}\text { Fruit } \\
\text { yield }\end{array}$ \\
\hline Fruit weight & I & & & & & & & & & & \\
\hline Fruit volume & $.988 * *$ & 1 & & & & & & & & & \\
\hline Fruit length & $.817 * *$ & $.820 * *$ & I & & & & & & & & \\
\hline Fruit breadth & $.819 * *$ & $.824 * *$ & $.874 * *$ & I & & & & & & & \\
\hline Fruit size & $.836 * *$ & $.842 * *$ & $.962 * *$ & $.97 I^{* *}$ & I & & & & & & \\
\hline Stone weight & .142 & .173 & .198 & .158 & .188 & I & & & & & \\
\hline Pulp weight & $.998 * *$ & $.984 * *$ & $.811 * *$ & $.815^{* *}$ & $.83 I^{* *}$ & .090 & I & & & & \\
\hline Pulp/stone ratio & $.670 * *$ & $.637 * *$ & $.478 * *$ & $.518^{* *}$ & $.504 * *$ & $-.611 * *$ & $.710 * *$ & I & & & \\
\hline Total soluble solids & $.317^{*}$ & .283 & .234 & .191 & .212 & $-.323 *$ & $.335^{*}$ & $.491 * *$ & I & & \\
\hline Fruit numbers & .223 & .256 & .265 & .233 & .250 & -.068 & .226 & .184 & .101 & I & \\
\hline Fruit yield & $.573 * *$ & $.597 * *$ & $.540 * *$ & $.510 * *$ & $.535 * *$ & .039 & $.574 * *$ & $.388 * *$ & .181 & $.914 * *$ & I \\
\hline
\end{tabular}

**Correlation is significant at the 0.0 I level (2-tailed)

*Correlation is significant at the 0.05 level (2-tailed)

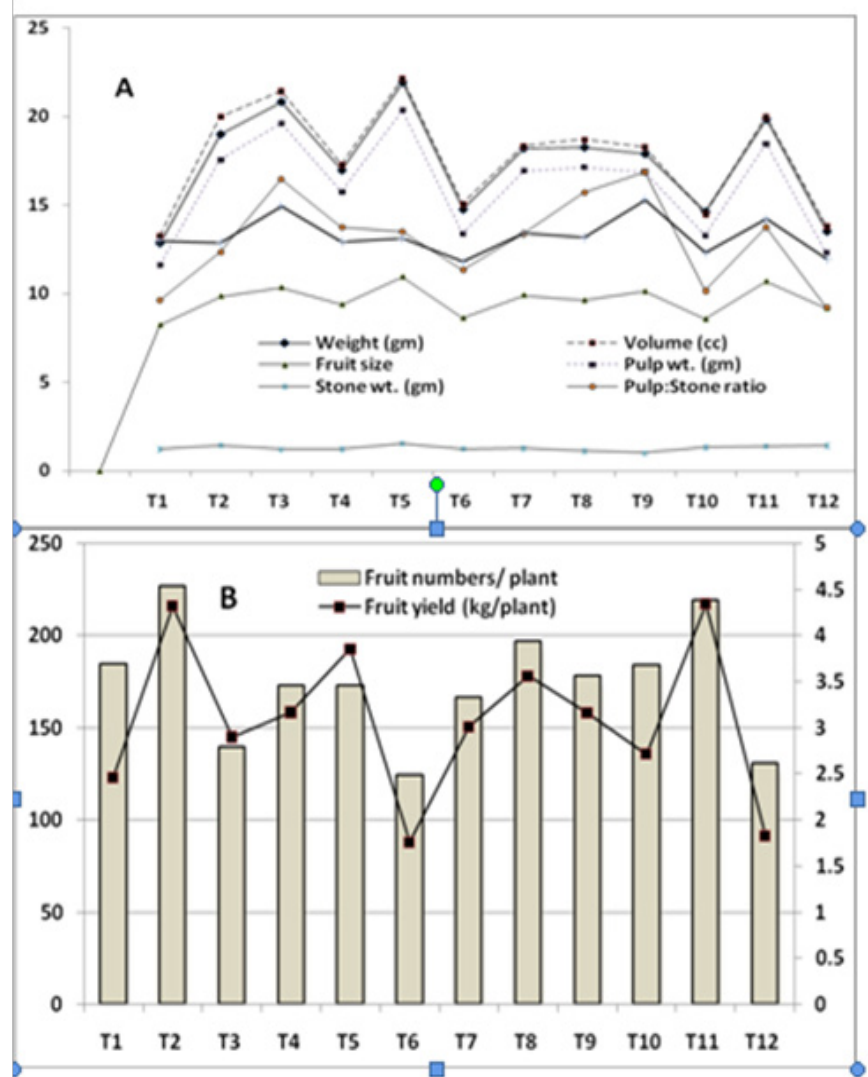

Figure I Efficacy of HiFoliar nutrient and potassium nitrate $\left(\mathrm{KNO}_{3}\right)$ spray on fruit characters $(\mathrm{A})$ and fruit numbers and yield of ber (cv Seo) in Central India (B). $\mathrm{T}_{1}$ - HiFoliar 0.2\%, $\mathrm{T}_{2}$ - HiFoliar 0.3\%, $\mathrm{T}_{3}$ - HiFoliar 0.4\%, $\mathrm{T}_{4}-\mathrm{KNO}_{3} 0.5 \%$, $\mathrm{T}_{5}-\mathrm{KNO}_{3} \mathrm{I} .0 \%, \mathrm{~T}_{6}-$ HiFoliar $0.2 \%+\mathrm{KNO}_{3} 0.5 \%, \mathrm{~T}_{7}-\mathrm{HiFoliar} 0.2 \%+\mathrm{KNO}_{3} \mathrm{I} .0 \%$, $\mathrm{T}_{8}$ HiFoliar $0.3 \%+\mathrm{KNO}_{3} 0.5 \%, \mathrm{~T}_{9}-$ HiFoliar $0.3 \%+\mathrm{KNO}_{3} \mathrm{I.0 \%}, \mathrm{T}_{10}-\mathrm{HiFoliar}$ $0.4 \%+\mathrm{KNO}_{3} 0.5 \%, \mathrm{~T}_{11}-$ HiFoliar $0.4 \%+\mathrm{KNO}_{3} \mathrm{I} .0 \%$ and $\mathrm{T}_{12}-$ Control.

\section{Conclusion}

The findings of the present investigation, apart from scientific value, have field implications for increasing yield and quality of ber fruits. The HiFoliar nutrient works only when it is used in combination with $\mathrm{KNO}_{3}\left(\mathrm{~T}_{11}\right)$ whereas application of $1.0 \%$ solution of $\mathrm{KNO}_{3}\left(\mathrm{~T}_{5}\right)$ only appear more effective as it produced comparable results with $\mathrm{T}_{11}$ in respect to most of the fruit characters. Thus, considering extra expenditure involved in treatment $\mathrm{T}_{11}$ by spraying HiFoliar nutrient in combination with $\mathrm{KNO}_{3}$, three spray of $1.0 \%$ solution of $\mathrm{KNO}_{3}$ $\left(\mathrm{T}_{5}\right)$ alone at the interval of 15 days from the marble stage of fruit is recommended for better fruit quality and yield of ber (Zizyphus mauritiana Lamk.) Cv. Seo in semi-arid region of Central India.

\section{Acknowledgments}

None.

\section{Conflicts of interest}

Authors declare that there is no conflict of interest.

\section{References}

1. Mukhtar HM, Ansari SH, Ali M, et al. New compounds from Zizyphus vulgaris. Pharmaceutical Biology. 2004;42(7):508-511.

2. Jin-Wei L, Liu-Ping F, Shao-Dong D, et al. Nutritional composition of five cultivars of chinese jujube. Food Chemistry. 2007;103(2):454-460.

3. Boora RS, Bal JS. Status of Indian jujube (Zizyphus mauritiana Lamk) in irrigated sub-humid and arid irrigated eco-system of Punjab. International Jujube Symposium. Baoding, China; 2008;21-25.

4. Singh RS. Note on the effect of intercropping on growth and yield of ber (Z. mauritiana) in semi-arid region. Curr Agric. 1997;21(1-2):117-118.

5. Yeshitela T, Robbertse PJ, Stassen PJC. Potassium nitrate and urea sprays affect flowering and yield of 'Tommy Atkins' Mangifera indica mango in Ethiopia. South African Journal of Plant and Soil. 2005;22(1):28-32. 
6. Kassem HA, El-Kobbia Amal M, Marzouk Hend, et al. Effect of foliar sprays on fruit retention, quality and yield of Costata persimmon trees. Emir J Food Agric. 2010;22(4): 259-274.

7. Kumar S, Kaurav GS, Prasad R. Effect of HiFoliar nutrients and potassium nitrate on growth and yield characters of ber (Zizyphus mauritiana Lamk) Cv Seo. Indian Journal of Agroforestry. 2014;16(2):53-59.

8. Gomez KA, Gomez AA. Statistical Procedure for Agricultural Research (Second Edition). Shree Maitrey Printech Pvt. Ltd., Noida, Indi; 2010.

9. Hegazi ES, Samira M, Mohamed MR, et al. Effect of potassium nitrate on vegetative growth, nutritional status, yield and fruit quality of olive cv. "Picual". Journal of Horticultural Science \& Ornamental Plants. 2011;3(3):252-258.

10. Nijjar GS. Nutrition of Fruit Trees. Usha Raj Kumar for Kalyani Publisher, New Delhi, India; 1985.

11. Elsabagh AS. Effect of bunches spraying with some macro and micronutrients on fruit retention and physical characteristics of "Deglet Nour" date palm cultivar during Kimiri stage. Res J Agric Biol Sci. 2012;8(2):138-146.

12. Yasin M, Ashraf M, Yaqub J, et al. Control of excessive fruit drop and improvement in yield and juice quality of Kinnow" (Citrus deliciosa $\times$ Citrus nobilis) through nutrient management. Pak J Bot. 2012;44:259265.

13. Inglese P, Gullo G, Pace LS. Fruit growth and olive oil quality in relation to foliar nutrition and time of application. Acta Hort. 2002;586:507-509.
14. Ben-Mimoun M, Loumi O, Ghrak M, et al. Foliar potassium application on olive tree. Regional Workshop on Potassium and Fertigation Development in West Asia and North Africa, Rabat, Morocco. 2004;24 28.

15. Sarrwy SMA, Mohamed EA, Hassan HSA. Effect of foliar spray with potassium nitrate and mono-potassium phosphate on leaf mineral contents, fruit set, yield and fruit quality of Picual olive trees grown under sandy soil conditions. American-Eurasian J Agric and Environ Sci. 2010;8(4):420-430.

16. Mengel K, Kirkby EA. Principles of plant nutrition. $5^{\text {th }}$ edn. Kluwer Academic Publishers, United States; 2001.

17. Shahin M. Effect of potassium fertilization on growth, leaves nutrient content, and yield of "khalas" date palm in al-hassa oasis (k.s.a). the fourth symposium on date palm in Saudi Arabia (Challenges of processing, marketing, and pests control), Date palm research center, king faisal university,al-hassa. 5-8 May, 2007. Abstracts Book. 2007;77.

18. Khayyat M, Tafazoli E, Eshghi S, et al. Effect of nitrogen, boron, potassium and zinc on yield and fruit quality of date palm. AmericanEurasian J Agric \& Environ Sci. 2007;2(3):289-296.

19. Stino RG, Abd El-Wahab SM, Habashy SA, et al. Productivity and frui quality of three mango cultivars in relation to foliar sprays of calcium, zinc, boron, or potassium. J Hort Sci Ornamen Plants. 2011;3(2):91-98.

20. Abbasi FF, Baloch MA, Zia-ul-hassan, et al. Growth and yield of okra under foliar application of some new multi- nutrient fertilizer products. PakJ Agri Agril Engg Vet Sci. 2010;26(2):11-18. 